\title{
Comments
}

\section{CALIFORNIA PRETRIAL IN ACTION}

\section{INTRODUCTION}

The pretrial conference is a part of practically every civil action litigated in California superior courts. Since the adoption of the mandatory pretrial rules in 1957, there has been considerable debate about the efficacy of the rules and their administration. Many argue that the pretrial conference has caused swifter and more accurate disposition of civil cases. Others contend that the conference is a waste of tine. Unfortunately, neither of these views has been adequately documented.

This Comment is the report of an attempt to measure the effect of mandatory pretrial conferences upon the processing of civil cases. To gather the desired information, a compreliensive questionnaire was sent to judges and attorneys throughout Cahifornia. One part of the questionnaire asked for replies based on personal observations. The judges and attorneys were asked for their observations of the inpact of pretrial upon preparation for trial, upon the number and time of settlements, and upon the length of trial. Another part of the questionnaire was designed to gather replies based on opinion. Specific questions in this part asked for opinions about the optimum use of pretrial for civil actions in general and for personal injury and domestic relations actions in particular. Thus, to the extent that it was possible for the respondents to separate their observations from their opinions, the survey was more than an opinion poll.

In order to understand the results of the survey, it is necessary to be thoroughly acquaimted with the present California pretrial procedure. To provide this background, the following items are considered briefly: the pretrial rules; the interpretation of these rules by the courts; the pressure to amend the rules; and the related provisions of California law. The philosophy of pretrial is then discussed as a prelude to the presentation of the survey procedure and the survey findings.

II

THE CALIFORNIA PRETRIAL CONFERENCE

\section{A. The Rules}

As its name suggests, the pretrial conference is a conference prior to trial between the pretrial judge and the opposing counsel. Its purpose is to bring about agreement on a simplified trial agenda, if, at the time of the conference, a trial still appears necessary. ${ }^{1}$ The conference is held after issue is joined ${ }^{2}$ and after discovery is substantially completed. ${ }^{3}$ Without adjudicating controverted

1 CAL. SUPER. CT. R. 8.4, 8.5.

2 CaI. Super. CT. R. 6(a).

3 CAL. Super. CT. R. 8.2 (d). 
facts, the pretrial judge may consider any matter, including settlement, ${ }^{4}$ that will aid in the disposition of the case. ${ }^{5}$

At the conclusion of the conference, the judge renders a pretrial order setting forth the matters agreed upon and enumerating the remaining issues of law and fact. ${ }^{6}$ Unless modified at or before trial, the order supersedes inconsistent pleadings.?

The California rules are similar to the federal rules ${ }^{8}$ as to the scope of the conference $^{a}$ and as to the effect of the order; ${ }^{10}$ they differ from the federal rules, however, by providing for the pretrial of every civil case. ${ }^{11}$

\section{B. Judicial Interpretation of the Rules}

The California courts have given the rules the force of law. ${ }^{12}$ It has been held that failure to hold a pretrial conference is error, though not necessarily reversible error. ${ }^{13}$ If the conference takes place and a pretrial order is filed, the courts have sanctioned the rule that the order, unless modified, supersedes mconsistent pleadings. ${ }^{14}$ De Castro v. Liberty S.S. Co. ${ }^{15}$ illustrates the reach the appellate courts have given this rule. The court held that if the pretrial order does not preserve the issue of whether the complaint states a cause of action, then that issue is no longer in the case. ${ }^{16}$ If the De Castro holding is correct, the pretrial conference is the last point at which a party may question the complaint's failure to state a cause of action, unless a subsequent motion to modify the pretrial order is successful. ${ }^{17}$

4 Cax. Super. CT. R. 8.5 .

5 The judge may consider and act upon: (1) pretrial statements of counsel; (2) amendments to the pleadings; (3) simplifications of factual and legal issues; (4) admissions of facts and documents; (5) references to commissioners or referees; (6) jurisdictional matters; (7) discovery matters; (8) requirements for trial briefs or for memoranda of points and authorities; (9) estimates of time for trial; and (10) assignments of the date and place of trial. Car. SUPER. CT. R. 8.4(a).

${ }^{\circ}$ Cat. SUPer. CT. R. 8.6.

7 CAI. SUPER. CT. R. 8.8.

8 The pretrial rules of most other states are based on FED. R. Crv. P. 16.

9 Compare Fed. R. Crv. P. 16 with Cad. SupER. Cr. R. 8.4, 8.5.

10 Compare Fed. R. Crv. P. 16 with CaL. Super. CT. R. 8.8.

11 Compare Fed. R. Crv. P. 16 with CAI. Super. Cr. R. 8. Short causes (trials estimated to take two hours or less) and trials de novo are excepted from the mandatory requirement. CAL. SUPER. CT. R. 8, 9, 9.5. The only other states to provide for mandatory pretrial by statewide rule are Michigan and New Jersey. King, Judicial Administration: California Adopts the Pretrial Conference, 44 A.B.A.J. 962 (1958). See Mich. CT. R. 35, 352 Mich. xv (1959); N.J. RUIES 4:29-1.

12 Cantillion v. Superior Court, 150 Cal. App. 2d 184, 309 P.2d 890 (1957). The court cited CaL. Const. art. VI, § 1a, for the proposition that the California Judicial Council's rules of practice and procedure, including rules adopted under specific statutory mandate, havc the force of law when not inconsistent with any legislative enactment.

13 American Home Assur. Co. v. Essy, 179 Cal. App. 2d 19, 3 Cal. Rptr. 586 (1960).

14 CAL. Super. CT. R. 8.8. See cases cited note 18 infra.

15186 Cal. App. 2d 628, 9 Cal. Rptr. 107 (1960).

16 Accord, Perry v. Thrifty Drug Co., 186 Cal. App. 2d 410, 9 Cal. Rptr. 50 (1960). In this case, the plaintiff failed to allege or prove that he had given the defendant notice of a breach of warranty. The trial court non-suited the plaintiff. The district court of appeals reversed, holding that the issue of lack of notice had not been preserved by the pretrial order and that the fact of notice was therefore established.

17 There have been no cases imterpreting the standard for modification of the pretrial order, "to prevent mamifest injustice." CaL. Super. CT. R. 8.8. Cf. CaL. Code Civ. Proc. § 473, 
The issues preserved in the pretrial order also control the introduction of evidence at the trial. If a party attempts to introduce evidence extrinsic to the issues of the order, a timely objection thereto will be sustained. ${ }^{18}$ On the other hand, evidence of matters outside the issues of the order has sometimes been imtroduced without objection. If there has been no showing of surprise by the opposing party, then an amendment of the pleadings to conform to the proof has been upheld on appeal. ${ }^{10}$ It is probable, however, that the proper way to re-introduce an issue into the case is to move to amend the pretrial order, rather than to move to amend the pleading. ${ }^{20}$

The order may thus add to, subtract from, or leave unchanged the issues in the pleadings. ${ }^{21}$ In general, it nnay be observed that the pretrial order does "rather strange things to conventional pleadings and the rules concerning them."22

which provides that after notice to the adverse party, the court, in its discretion, may allow an amendment to the pleadings "upon such terms as may be just." See 2 WIrkIN, CaIrForNIA Procedure \$\$ 590-613 (1954) for a comprehensive anaiysis of the factors that the courts bave considered in determining whether to allow amendments to the pleadings.

${ }^{18}$ Lund v. Utter-McKinley Mortuaries, 186 Cal. App. 2d 162, 8 Cal. Rptr. 685 (1960). See also De Castro v. Liberty S.S. Co., 186 Cal. App. 2d 628, 9 Cal. Rptr. 107 (1960) ; Perry v. Thrifty Drug Co., 186 Cal. App. 2d 410, 9 Cal. Rptr. 50 (1960); Fitzsimmons v. Jones, 179 Cal. App. 2d 5, 3 Cal. Rptr. 373 (1960); Dell 'Orto v. Dell 'Orto, 166 Cal. App. 2d 825, 334 P.2d 97 (1959); Baird v. Hodson, 161 Cal. App. 2d 687, 327 P.2d 215 (1958).

19 Collison v. Thomas, 55 Cal.2d 491, 360 P.2d 51, 11 Cal. Rptr. 555 (1961); Vesci v. Ingrim, 190 A.C.A. 481, 11 Cal. Rptr. 830 (1961); Rocky Mountain Export Co. v. Colquitt, 179 Cal. App. 2d 204, 3 Cal. Rptr. 512 (1960). See Vick v. Grasser, 169 Cal. App. 2d 692, 338 P.2d 223 (1959). Cf. Mici. CT. R. 35 § 4(12), 353 Mich. xv, xvi (1959):

No party shall be deprived of the right to present competent proof at the trial in support of any issues raised in the pleadings unless such issues bave been expressly waived at the pretrial conference and such waiver is recorded in the said summary of results.

(Emphasis added.)

20 The pretrial rules specify the proper way to modify the pretrial order. If possible, any objection to the order should be taken at the conference. If the judge does not sustain the objection and amend the order, then a request to correct or to modify the order should be served and filed during the five days prior to the filing of the order. CAx. SUPER. CT. R. 8.7 (b). After the order is filed, an objection is properly taken at or before trial by a motion to modify the order, not by a motion to amend the pleadings. CAL. SUPER. CT. R. 8.8. If the court overrules an objection prior to, or during, trial, it may be possible to obtain review by an extraordinary remedy. See Kroninger, Pre-Trial Conferences, Procedure Before Triar 751 (Cont. Ed. Bar 1957). If properly preserved, an objection to the pretrial order provides a ground for appeal from a final judgment. Cax. SUPER. CT. R. 8.10.

21 Rule 8.8 provides that, where inconsistent with the pleadings, the pretrial order controls the subsequent course of the action. Simce CaI. ConsT. art. VI, \& 1a gives the Judicial Council power only to provide rules that are not imconsistent with existing or future laws, consider the possible conflict of Rule 8.8 with: (1) CAx. CODE Crv. PROC. \& 426(2) requiring the complaint to state facts constituting a cause of action; (cf. FeD. R. CIv. P. 8(a), which requires plaimtiff to state only a claim showing entitlement to relief); (2) CAL. CODE CIv. Proc. $\$ 589$ stating that an issue of law arises on a deinurrer to the complaint or to the answer; (3) CaI. CODE Crv. Proc. $\S 591$ providing that an issue of law must be tried by the court unless waived; (4) CaL. Code CTV. Proc. $\S 434$ stating that if an objection is not taken by demurrer or answer, then it is waived, except the objection that the complaint does not state facts sufficient to constitute a cause of action; (5) CAL. CODE Crv. Proc. \$ 452 requiring the allegations of a pleading to be liberally construed; (6) CAX. CODE Crv. PROC. $\S 462$ providing that if a material allegation of the complaint is not controverted, then the allegation is deemed to be true; and (7) CAI. CODE Crv. Proc. \& 469-70 stating that if there is no material variance, then the court may order an amendment of the pleadings to conform to the proof.

2253 AM. JUR. Trial § 11 (Supp. 1961). 


\section{The Pressure to Amend the Rules}

To understand the present status of pretrial in California, reference must be made to the manner in which the rules were adopted and to the current pressure to amend the rules.

Pursuant to a legislative resolution, ${ }^{23}$ the California Judicial Council made a study of pretrial ${ }^{24}$ and, in its 1954 report, recommended that pretrial be adopted by rule rather than by statute. ${ }^{25}$ The Council felt that it would be in a better position than the legislature to supervise the operation of the rules and to make timely amendments to them. ${ }^{26}$ At the 1955 session, the legislature enacted Code of Civil Procedure section 575, providing that the Judicial Council may promulgate rules governing pretrial conferences. ${ }^{27}$ In September, 1956, the Council adopted pretrial rules for the superior courts, effective January $1,1957 .^{28}$ Thus, in the existing framework, there are two ways to amend the rules: (1) the Judicial Council may itself change the rules; or (2) the legislature may amend section 575 to restrict or to expand the scope of the rules.

Despite resistance to mandatory pretrial, ${ }^{29}$ the Judicial Council has made only one minor modification of the rules since their adoption in $1956 .{ }^{30}$ In 1960 , however, the Council published proposed changes designed to strengthen the present rules, ${ }^{31}$ but to date the Council has taken no action on these changes. While the Judicial Council has proposed changing the rules to reinforce mandatory pretrial, the legislature and the Conference of State Bar Delegates have considered proposed code amendments that would undermine mandatory pretrial. In 1961, the legislature considered a bill ${ }^{32}$ that would have divested the Judicial Council of its power to require pretrial in every case. ${ }^{33}$ The bill passed the Assembly, but the Senate Committee on the Judiciary referred it to the Assembly Committee on Rules too late in the session for action to be com-

23 Cal. Stats. 1949 ch. 191, p. 3406-07 (A.C.R. 92).

24 The Los Angeles and San Francisco courts used the pretrial conference in the late 1930's. See Note, 30 CaLIF. L. Rev. 212 (1942); Pre-Trial Sabotage in Los Angeles, 23 J. Ax. Jud. Soc'Y 241 (1940); Pre-Trial Challenges Lawyers' Influtence, 23 J. Ax. Jud. Soc'Y 69 (1939); Timid Use of Pre-Trial in San Francisco, 22 J. Ax. Jud. Soc'y 138 (1938).

2515 Cat. Judictal Counctr BIennial Rep. 13-21 (1953-1954).

$261 d$. at $20-21$.

27 Cf. CAx. Const. art. VI, \& 1a, which provides that the Judicial Council may promulgate court rules not inconsistent with law. It is not known whether the Council could have provided for pretrial without the specific mandate of CaL. Code CIv. Proc. $\$ 575$.

${ }^{28}$ CAT. SUPER. CT. R. 6, 8-8.8, 9, 9.5, 12, 32. The rules were published in $47 \mathrm{Cal} .2 \mathrm{~d}$ at $3-9$ (1957).

29 See Conference Actions, 34 Car. S.B.J. 107 (1959) (Conference of State Bar Delegates, resolution No. 50 ).

${ }^{30}$ See 50 Cal. 2 d 71 (1959).

3135 CAx. S.B.J. 461-71 (1960). The proposed changes would require: (1) a certificate of readiness to be filed in heu of the memorandum to set; and (2) discovery to be completed before the pretrial hearing. The proposal would also increase the sanctions available to the pretrial judge.

32 This bill was similar in substance to a resolution of the Conference of State Bar Delegates. See note 29 supra.

33 The bill would have added the following to CAt. ConE Crv. Proc. § 575: "[P]rovided, that such rules shall not make pretrial conferences mandatory, but rather shall provide for such conferences on order of the court, in its discretion, or on application of any party to tbe case. Any rule of the Judicial Council heretofore or hereafter adopted purporting to make pretrial conferences mandatory shall be construed as authorizing such conferences on order of the court or on application of a party." A.B. 1745, Cal. Leg, Reg. (Gen.) Sess. (1961). 
pleted. ${ }^{34}$ Most observers are of the opinion that the bill would have passed the Senate if it had reached the floor and that, barring changes to the rules, the bill will be introduced at the 1963 session. ${ }^{35}$ Thus, at present, there is substantial pressure to aniend the rules. Facing the possible loss of its power to provide for mandatory pretrial, the Judicial Council will probably change the rules before the legislature convenes in $1963 .^{36}$

\section{Related Provisions of the California Law}

To place pretrial in a proper procedural context, it is necessary to outline soine of the related provisions of California law. The most closely related procedure is the settlement conference, a progeny of pretrial. ${ }^{37}$ The conference is conpletely voluntary, being held only if each party to the case requests it. ${ }^{38}$ Since discussion of settlement is the purpose of the conference, the parties, or someone with authority to settle, must attend or be immediately available. If the case is not settled, the judge either draws a pretrial order or sets the case for a future pretrial conference.

Discovery is another Cahifornia procedure intimately related to pretrial. ${ }^{39}$ The similarity of these two procedures is apparent ${ }^{40}$ fron the California Supreme Court's statement of the purpose of the Discovery Act of 1957:41

(1) to give greater assistance to the parties in ascertaining the truth and in checking and preventing perjury; (2) to provide effective means of detectimg and exposing false, fraudulent and sham claims and defenses; (3) to make available, in a simple, convenient and inexpensive way, facts which otherwise could not be proved except with great difficulty; (4) to educate the parties in advance of the trial as to the real value of their claims and defenses, thereby encouraging settlements; (5) to expedite litigation; (6) to safeguard against surprise; (7) to prevent delay; (8) to simplify and narrow the issues; and (9) to expedite both preparation and trial.42

34 Final Calendar 508, Cal. Leg., Reg. (Gen.) Sess. (1961).

35 Letter from Edwin L. Z'berg, sponsor of A.B. 1745, to the author, August 16, 1961, on file at the California Law Review office.

36 See note 122 infra for an explanation of a current pretrial experiment in Los Angeles. This procedure may be the prototype for a change in the rules by the Council.

37 The settlement conference was initiated in Los Angeles by a policy memorandum concerning pretrial. XXXVII METRopoLitan NEws (Los Angeles) No. 168 at 8 (1959). The settlement conference is used in at least two other counties: Alameda and San Francisco. 18 CaI. Judicial CouncII BIENNIAI Rep. 126 (1959-1960).

38 This explanation is based on the Los Angeles settlement conference. XXXVIII METroPOLITAN NEWS (Los Angeles) No. 168 at 8 (1959).

39 See CaL. Code Crv. Proc. $\S \S 2016-35$ for the California discovery procedures. These sections were added by the Discovery Act of 1957 (Cal. Stats. $1957 \mathrm{ch} .1904$ ) and were patterned after FED. R. Crv. P. 26-37. See Greybound v. Superior Court, 56 A.C. 353, 373, 364 P.2d 266, 274-75, 15 Cal. Rptr. 90, 98-99 (1961). Under the federal rules, discovery and pretrial have been described as extensions of the pleadings. Thus conceived, the pleadings serve to give notice to the adversary of the clain or the defense; discovery serves to gather information about the controversy; and pretrial serves to define the issues in preparation for trial. Fee, The Last Horizon in Pleading Under the Federal Rules of Civil Procedure, 48 Coxum. L. Rev. 491 (1948). Compare FED. R. Crv. P. 8(a) (requires the plaintiff to state a claim showing entitlement to relief) with CAL. CODE Crv. Proc. $\S 426(2)$ (requires the complaint to state "facts" constituting a cause of action).

40 See text at notes 57-70 infra for a statement of the purpose of pretrial.

41 Since the survey was partly conducted on a "before" and "after" basis, i.e., respondents were asked to compare non-pretried cases prior to 1957 with pretried cases subsequent to 1957 , it is probable that the survey results were affected by the adoption of the more liberal discovery procedures in 1957. In many cases, respondents must have found it difficult to distinguish the effects of discovery from the effects of pretrial upon civil adjudication.

42 Greyhound Corp. v. Superior Court, 56 A.C. 353, 374, 364 P.2d 266, 275, 15 Cal. Rptr. 90,99 (1961). 
In addition, it has been frequently observed that pretrial may be used as a device to "discover" additional facts. ${ }^{43}$

If discovery and pretrial demonstrate that no triable issue of fact ${ }^{44}$ remains in the case, then, on motion, the court may enter a summary judgment. In opposition to a motion for summary judgment, however, a party may file an affidavit controverting only a part of the claim. The court will then render a partial summary judgment order establishing the claim to the extent that it is not controverted..$^{45}$ The case is then tried on the issues not eliminated by the order..$^{40}$ The partial summary judgment order is thus similar to the pretrial order, both seeking to define the issues in dispute.

Although it may not be strictly accurate to describe Cahifornia pretrial as "one unit in an integrated system of rules," a number of [procedures] . . . that have for their direct objective simplification and expedition." 48

\section{III}

\section{SURVEY GUIDELINES AND PROCEDURE}

\section{A. Survey Guidelines}

With the California pretrial provisions as a background, the philosophy of pretrial is now discussed as a guide to the presentation of the survey procedure.

\section{Pretrial and the Adversary System}

Many lawyers object to pretrial because they feel that it is inimical to the adversary system. They argue that the parties should control the proceedings prior to the trial..$^{49}$ If the parties cannot resolve their controversy, then they bring it to trial. Under this theory, unless one of the parties files a preliminary motion, the judge first enters the case at trial, not prior to trial. The judge takes the case as it is presented to him by the parties in the pleadings, ${ }^{50}$ and not as the case is presented, through his intervention, in the pretrial order. The truth

43 See, e.g., Kroninger, Pre-Trial Conferences, Procedure Before Trial 735 (Cont. Ed. Bar 1957); Nelson, Pre-Trial-An Effective Weapon of Advocacy, 4 U.C.L.A.L.REv. 381, 393-94 (1957); Pickering, The Pre-Trial Conference, 9 Hastngas L.J. 117, 125 (1958).

44 Cf. CaI. Super. CT. R. 8.4(b). If the parties so stipulate, the court may determine any matter, including controverted facts, at the pretrial conference. For the only reported case involving the use of this device, see Hall v. San Jose Abstract \& Title Ins. Co., 172 Cal. App. 2d 421, 342 P.2d 362 (1959).

45 Car. Code Crv. Proc. \$437(c). See 2 Witknn, Calmfornia Procedure $\$ 80$ (1954). The author indicates that partial summary judgment may be available only to a plaintiff. Cf. FED. R. Crv. P. 56(d) (partial summary judgment available to both parties).

46 Cf. CAL. Code CIv. Proc. $\$ 597$. Upon a motion by either party, the court may order a separate trial of any defense not involving the merits and constituting a bar to, or a ground for abatement of, the action. If the court finds for the defendant, then the court will enter an interlocutory judgment in his favor. If the court finds for the plaintiff, then, on motion, the court will order a trial on the remaining issues.

47 Professor Louisell thus describes federal pretrial. Louisell, Discovery and Pre-Trial Under the Minnesota Rules, 36 MrNw. L. REv. 633 (1952).

48 As Louisell further describes federal pretrial. Id. at 633 .

49 Kuykendall, Pretrial Conference: $A$ Dissent from the Bar, 45 VA. L. REv. 147 (1959). Cf. Sunderland, The Theory and Practice of Pre-Trial Procedure, 36 MrcH. L. REv. 215, 215-16 (1937).

50 Sunderland, supra note 49, at 215-16. Professor Sunderland describes this as the principle of "party presentation." 
emerges at trial through a tightly regulated, but highly contested, battle between vitally interested partisans..$^{51}$

On the other hand, many beheve that pretrial strengthens, rather than weakens, the adversary system..$^{52}$ One author has stated this philosophy of pretrial: "Pre-trial is not an attempt to obviate the struggle that is common law litigation, but to guarantee that the struggle will be real, not sham, and that the battles will be fought out in the heartland of the controversy, not on the fringes." considered, the lawsuit is a search for the truth, ${ }^{54}$ and there is no valid reason why the judge should not participate in the search prior to trial.55 Although an ill-prepared attorney stands to gain by his opponent's disclosures at the pretrial conference, he also stands to lose by his own inability to ensure that lis chent's case is properly presented at the pretrial conference and is properly reflected in the pretrial order. ${ }^{56}$

\section{Pretrial Objectives}

Pretrial was initially adopted in this country to meet the problem of court delay. ${ }^{57}$ This aspect of pretrial has proved attractive to courts and legislatures considermg its adoption. ${ }^{58}$ But there is considerable dispute whether pretrial realizes all or any of the following objectives: (1) to save court time; ${ }^{59}$ (2) to save attorney time; ${ }^{60}$ (3) to increase the number of settlements; ${ }^{61}$ (4) to promote earlier settlements; ${ }^{62}$ (5) to encourage more jury waivers; ${ }^{63}$ (6) to shorten trials; ${ }^{84}(7)$ to dispose of preliminary matters (amendments, admissions, etc.) ${ }^{85}$ and (8) to narrow and define the issues of law and fact. ${ }^{68}$

51 See Louisell, Discovery and Pre-Trial Under the Minnesota Rules, 36 Mnsv. L. REv. $633,640(1952)$.

52 Louiselt \& Witriams, Trial of Medicar Malpractice Cases 287 (1960); Belli, PreTrial: Aid to the New Advocacy, 43 CORNELx L.Q. 34 (1957); Louisell, supra note 51, at 660-68; Nelson, Pre-Trial-An Efjective Weapon of Advocacy, 4 U.C.L.A.L. REv. 381 (1957).

63 Louisell, supra note 51, at 660-61.

54 The United States Supreme Court has described federal pretrial, coupled with discovery, as a device to narrow and to clarify the issues so that trials "no longer need be carried on in the dark." Hickman v. Taylor, 329 U.S. 495, 501 (1947). See Greyhound v. Superior Court, 56 A.C. 353, 374, 364 P.2d 266, 275, 15 Cal. Rptr. 90,99 (1961), in which the court stated that the legislature, by enacting the Discovery Act of 1957 (Cal. Stats. 1957 ch. 1904), intended to take the game element out of trial preparation.

${ }^{55}$ Sunderland, supra note 49, at 218-19; see Serini, Basic Features of Civil Procedure in Italy-A Comparative Study, 1 Axs. J. Coxp. L. 373 (1952).

56 See cases cited in note 18 supra.

57 See 3 Moore, Federat Practice 1107 (2d ed. 1948) ; Nims, Pre-Trial 3 (1950); Sunderland, supra note 49 , at 220 .

58 Cal. Stats. 1949 ch. 191, pp. 3406-07 (A.C.R. 92).

59 See Kroninger, Pre-Trial Conference, Procedure Before Triat 735 (Cont. Ed. Bar 1957).

60 Laws, Pre-Trial-A Trial Judge Looks at Pre-Trial Procedure, 4 Prac. Law. 17, 20 (1958).

61 See CaL. Super. CT. R. 8.5; Kroninger, op. cit. supra note 59, at 745-46.

62 See Cat. Surer. Cr. R. 8.5; Kroninger, op. cit. supra note 59, at 735.

63 See Thomas, The Story of Pre-trial in the Common Pleas Court of Cuyahoga County, Pre-Trial, A Symposium, 7 W. REs. L. Rev. 367, 372 (1956).

64 See, e.g., 17 F.R.D. 437, 441-42 (1955); CaL. Judicial Counci, Calffornia Manual of Pre-Trial Procedure 12 (1956); Fee, The Last Horizon in Pleading Under the Federal Rules of Civil Procedure, 48 CoLUM. L. Rev. 491 (1948); Sunderland, The Theory and Practice of Pre-Trial Procedure, 36 Mich. L. REv. 215, 218 (1937).

65 See Cat. Super. CT. R. 8.4(a).

B6 Ibid. 
The advocates of pretrial contend that pretrial results not only in swifter justice, but also in better justice ${ }^{67}$ Pretrial is said to diminish the chance of a case being won or lost by surprise at trial. ${ }^{68}$ Since the essential issues of the case are exposed at the conference and defined in the order, court and counsel niay direct their efforts nore efficiently and thus will be better prepared for a trial on the merits. ${ }^{69}$ The opponents reply that the experienced, well-prepared attorney acconphishes the same objectives without pretrial. ${ }^{\text {70 }}$

\section{B. Survey Procedure}

A critical evaluation of the interrelation of pretrial and the adversary system involves a study of subjective value judgments that by their nature preclude factual analysis. This objection, however, is no barrier to a statistical study of many of the objectives of pretrial. The survey was thus directed to analyzing the most readily observable effects 'of pretrial, e.g., the effect upon length of trials. Since adequate state-wide ${ }^{71}$ judicial statistics were unavailable ${ }^{72}$ the method chosen was designed to collect the observations as well as the opinions of experienced pretrial judges and attorneys. Comprehensive questionnaires ${ }^{73}$ based on a recent survey ${ }^{74}$ by the Columbia University Project for Effective Jus-

67 The advocates of pretrial divide as to optimum use of pretrial. Some argue that pretrial benefits every case and that the conference should be mandatory. 17 F.R.D. 437,451 (1955); 17 Cal. Judicial Council BIennial Rep. 56 (1957-1958). Others contend that pretrial is a waste of time in many cases. See, e.g., CAL. SupEr. Cr. R. 8, 9, 9.5 (short causes and trials de novo are excepted from mandatory pretrial); N.J. RuLEs 4:29-1(a) (divorce actions are excepted); 20 F.R.D. 500 (1957) (questions whether simple personal injury actions should be pretried). But see Brennan, After Eigltt Years: New Jersey Judicial Reform, 43 A.B.A.J. 499,564 (1957) (greatest benefit from pretrial in personal injury cases). Still others argue that the need for flexibility requires the conference to be optional rather tban mandatory. See, e.g., Louisell, Discovery and Pretrial Under the Minnesota Rules, 36 MrNn. L. Rev. 633, 661, 667 (1952); Pickering, The Pre-Trial Conference, 9 Hastrngs L.J. 117, 119-20 (1958); Letter (undated) to Harry Nims from Ira W. Jayne, Chief Judge of the Circuit Court, Wayne County, Mich. (the founder of modern pretrial), quoted in NIMS, PRE-TRIAI 16-17 (1950).

68 See, e.g., Hickman v. Taylor, 329 U.S. 495, 501 (1947); 3 Moore, Federal Practice $1104,1106-07,1115$ (2d ed. 1948); Laws, supra note 60.

69 "The grand objective of a pretrial conference is to prepare the trial judge and counsel on each side for the best possible trial of the case." Vanderbilt, The First Five Years of the New Jersey Courts Under the Constitution of 1947, 8 RutGERS L. REv. 289, 298 (1954). See also Laws, supra note 60, at 19.

${ }^{70}$ Kuykendall, Pretrial Conference: A Dissent from the Bar, 45 VA. L. Rev. 147, 148 (1959). See also McCaskill, The Modern Philosophy of Pleading: A Dialogue Outside the Shades, 38 A.B.A.J. 123 (1952).

71 Since the California rules apply to all superior courts, the study was conducted on a state-wide basis.

72 The California Judicial Council is the central reservoir of superior court statistics. The Council attenipted to demonstrate the benefits of the pretrial conference in its biennial report for 1957-1958. Tbe reported statistics indicated that more cases per judge were disposed of during the period immediately subsequent to the introduction of pretrial (Marcb 1, 1957 to February 28, 1958) than during the previous twelve-month period. Moreover, while the number of cases resolved before trial increased, the proportion of cases requiring trial decreased. From this latter finding, it was concluded that pretrial had increased the number of voluntary settleinents. The Council carefully poimted out that many aspects of pretrial were not capable of statistical analysis by available court statistics. 17 CAL. JUdICIAL COUNCII BIENNIAL REp. 55 (1957-1958). In its next biennial report, the Council omitted a statistical analysis of pretrial, but again stated that court statistics do not demonstrate the full benefits of pretrial. 18 CAL. JUDICIAL COUNCII BIENNIAI REP. 126 (1959-1960).

73 See appendixes B and C. The questionnaires were mailed on August 31, 1961.

74 Rosenberg, Comparative Negligence in Arkansas: $A$ "Before and After" Survey, 13 ARK. L. REv. 89 (1959). 
tice, ${ }^{75}$ were addressed to all of California's 301 superior court judges ${ }^{76}$ and to 1200 California attorneys selected for their probable pretrial and trial experience.77 The first part of the questionnaires asked for general information about the respondents. In the second part, those judges and attorneys who had had trial experience prior to the introduction of pretrial were asked to report their personal observations of the impact of pretrial upon civil adjudication. All respondents were asked for their opinions about pretrial in the third part. In the final part of the questionnaires, the respondents were encouraged to expand their reactions to pretrial beyond the confines of the multiple-cloice questions of the preceding two parts.

Over lialf of those questioned replied. ${ }^{78}$ Moreover, the returns indicated that the respondents were on familiar terms with the subject of inquiry. ${ }^{79}$ The survey thus represents the observations of 86 judges and 410 attorneys ${ }^{80}$ and the opinions of 162 judges and 545 attorneys. ${ }^{81}$

The responses were analyzed according to information about the respondents requested in part one of the questionnaire. The judges' replies were collated with respect to (1) the size of the county where the judge's court is located, and (2) the extent of the judge's trial and pretrial experience. The attorney responses were processed by (1) the size of the county where the attorney conducts most of his practice, (2) the size of the attorney's firm, and (3) the attorney's trial and pretrial experience. If an attorney's reply indicated that his practice included substantial personal injury litigation, his reply was analyzed with reference to whether he was a plaintiff's attorney or a defendant's attorney.

It had been predicted that replies would differ according to the above variables. For example, it was hypothesized that respondents from smaller counties

75 The Project is presently conducting a controlled experiment on the operation of pretrial in New Jersey. Three groups of cases are being examined: (1) those mandatorily pretried; (2) those not pretried; and (3) those optionally pretried. Sovern, Proposed Revision of the New York Practice Act, 1959 Post-Graduate Conference at Columbia Law School, 60 Colvar. L. Rev. 50, 82-86 (1960); Columbia University Project for Effective Justice, Experiment to Test the Effectiveness of Pretrial Conferences in New Jersey (unpublished memorandum dated November 16, 1959). The method used in the New Jersey study has been described as the only decisive way to measure the effect of pretrial. ZIESEI, KaIVEN \& Bucranolz, DeLAY IN THE CoURT 143-44 (1959). Since New Jersey has mandatory pretrial, the results of this survey should be most interesting to California attorneys and judges.

76 The source of superior court judges was 54 Cal. 2d vi (1961).

77 The sources of lawyers were Martindale-Fubbedt, 1 Law DiRectory 89-331 (1961 ed.); Markeanis's Negligence Counser 21-42 (1960-61 ed.) ; Am. Acad. of Trial Lawwers, LiST OF MEMrBers (1960 ed.). Every third lawyer in the first two sources was included in the survey; all California members of the Academy were included.

78 Questionnaires were returned by 179 judges and 588 attorneys, a total of 767 . The questionnaires of 13 judges and 35 attorneys were not sufficiently completed to be tabulated. Twelve questionnaires were received after October 31 , too late to be collated. The replies are on file in the California Law Review office.

${ }^{79}$ See table 2 infra, which shows that $88 \%$ of the judges and $92 \%$ of the attorneys answering that particular question were included in the "much experience" category. If a judge reported that he spent $10 \%$ or more of his time in civil trials, or $5 \%$ or more of his time in pretrial conferences, his reply was included in the "much experience" category. If an attorney reported participation in 10 or more trials and 10 or more pretrial conferences, his reply was included in the "much experience" category.

80 These numbers are based on the highest number of respondents answering a particular question in the observation part of the questionnaire.

81 These numbers are based on the highest number of respondents answering a particular question in the comments part of the questionnaire. 
would be less receptive to pretrial than those from larger counties, because attorneys in the smaller counties know each other and customarily meet prior to trial to accomplish many of the objectives of the formal conference. ${ }^{82}$ Yet no significant differences in replies were attributable either to the size of the county of origin or to the other variables. In fact, the replies were more often significant because of their similarity in this respect. ${ }^{83}$

Three questions were included to determine whether the respondents were answering accurately and carefully. It was believed that if a respondent answered that pretrial caused fewer or later settlements, or longer trials, then the validity of his entire reply would be doubtful. Less than two per cent of the respondents offered the "wrong" observations that pretrial caused fewer settlements and longer trials. ${ }^{84}$ Yet five per cent of the judges and seven per cent of the attorneys reported that pretrial caused later settlements. Many respondents explained, however, that there is a tendency among attorneys to wait until the conference before beginning settlement negotiations. Some charged that defense counsel, who are paid on a per diem basis, deliberately wait until the conference before making serious attempts to settle, because the conference constitutes a court appearance chargeable to the client..$^{85}$ Others reported that attorneys find the pretrial judge's opimion of the case helpful in reaching a settlement. Hopefully, the latter view is more accurate.

By its nature a multiple-choice questionnaire cannot produce comprehensive replies. Respondents were therefore asked to volunteer additional comments in part four of the questionnaire. These comments, as well as personal interviews $s^{83}$ and personal observations of pretrial conferences, ${ }^{87}$ tended to confirm the survey findings which are now set forth.

\section{IV}

\section{SURVEY FINDINGS}

The survey results revealed much about California pretrial in action. While many of the findings were predicted, others were quite unexpected. As an aid to their analysis, the findings based on observations, the findings based on opinions, and the findings based on comments are presented separately.

\section{A. Findings Based on the Observations of Attorneys and Judges}

Based on their own observations, judges and attorneys were asked to compare non-pretried cases prior to 1957 with pretried cases subsequent to 1957.

82 See 20 F.R.D. 516 (1957).

83 Because of the method used to select the attorneys surveyed, and because of the possibility of a nonrepresentative distribution of returns from all those suryeyed, it may be that all of the sub-groups mentioned in the text were not equally represented in the survey responses. Since there is a possibility of unequal representation of sub-groups, the similarity of responses serves to strengthen the conclusions drawn.

84 See tables 1 and 2 infra.

85 See note 106 infra.

86 The author interviewed 25 judges and attorneys in June-August, 1961.

87 The author attended pretrial conferences in three Cahfornia counties and in the District of Columbia. 


\section{Time Factors}

\section{a. Settlement}

The survey shows a sharp difference between the reports of judges and the reports of attorneys on the effect of pretrial upon settlement. Almost two out of three judges observed the proportion of cases settled to be greater, while better than two out of three attorneys found the proportion of cases settled to be unchanged.

\section{TABLE 1.}

Effect of Pretrial upon Proportion of Setruements

$\begin{array}{lcccc} & \text { Greater } & \text { Smaller } & \text { Unchanged } & \text { Total } \\ & \% & \% & \% & \text { No.88 } \\ \text { Judges } & 64 & 1 & 35 & 92 \\ \text { Attorneys } & 28 & 1 & 71 & 460\end{array}$

In analyzing this response, it should be noted that the attorneys are probably in a better position to report on settlements. Although it is clear that pretrial has not had a negative influence upon the number of settlements, ${ }^{89}$ it is not safe to conclude that pretrial has brought about more settlements. ${ }^{90}$

Judges and attorneys followed the above pattern in their observations of the effect upon time of settlement. Thus, 62 per cent of the judges reported earlier settlements, while 66 per cent of the attorneys found the time of settlement unchanged.

\section{b. Jury Waivers}

The respondents decisively agreed that pretrial does not affect the number of jury waivers. 73 per cent of the judges and 94 per cent of the attorneys chose "unchanged" in reply to the jury waiver question. Apparently factors other than pretrial produce jury waivers. ${ }^{91}$

\section{c. Length of Trial}

A small majority of judges reported shorter trials because of pretrial. Attorneys, on the other hand, were decisive in reporting the length of trials to be unaffected by pretrial.

88 The numbers of judges and attorneys answering individual questions varies throughout the Comment because not all the respondents answered each question. As discussed in note 78 supra, many questionnaires were not processed because of substantial incompleteness.

89 Since the reply "smaller" was considered inaccurate, the question, in effect, asked only whether pretrial had caused a greater number of settlements.

90 See text at notes 37-38 supra for a discussion of the settlement conference as a progeny of the pretrial rules.

91 One superior court judge summarized the possible factors as follows: "... how various witnesses will appear on the stand, the form sheet of the present panel, evaluation of medical reports, the prestige of doctors who are going to testify, the earning capacity, appearance of hife expectancy of plaintiff, target value and insurance coverage of the defendant, the appearance and attitude [of] the defendant or his agent ...." 
TABLE 2.

EfFect of Pretrial upon Length of Truats

\begin{tabular}{lcccc} 
& $\begin{array}{c}\text { Longer } \\
\%\end{array}$ & $\begin{array}{c}\text { Shorter } \\
\%\end{array}$ & $\begin{array}{c}\text { Unchanged } \\
\%\end{array}$ & $\begin{array}{c}\text { Total } \\
\text { No. }\end{array}$ \\
$\begin{array}{l}\text { Judges } \\
\text { "Little }\end{array}$ & 2 & 54 & 44 & 98 \\
$\quad$ Experience" & 0 & 75 & 25 & 12 \\
$\begin{array}{c}\text { "Much } \\
\text { Experience" }\end{array}$ & 2 & 51 & 47 & 86 \\
$\begin{array}{c}\text { Attorneys } \\
\text { "Little }\end{array}$ & 1 & 27 & 72 & $450^{02}$ \\
$\quad \begin{array}{l}\text { Experience" } \\
\text { "Much } \\
\text { Experience" }\end{array}$ & 3 & 41 & 56 & 37 \\
\hline
\end{tabular}

This difference in observation between attorneys and judges is difficult to explain. Both judges and attorneys with considerable experience answered that the length of trials was unchanged more often than did those with less experience. Although it is not likely that pretrial causes longer trials, ${ }^{93}$ there is no clear indication that pretrial causes shorter trials.

\section{d. Total Time Spent on the Disposition of a Case ${ }^{94}$}

Judges and attorneys again differ in their reports of the effect of pretrial upon the time required to dispose of a case.

TABLE 3.

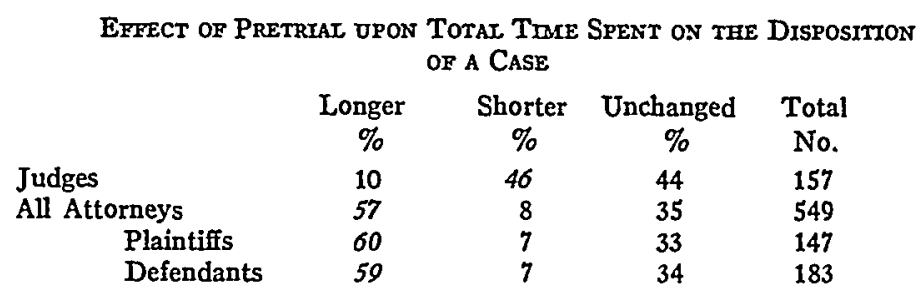

A majority of attorneys say that it takes them more time to dispose of a pretried case, while only ten per cent of the judges report that more judicial time is expended because of pretrial. It should be noted that these questions attempted to measure two distinct variables, judge time and attorney time. The difference in observation here is thus easier to explain than in previous questions that required responses concerning the same variable, e.g., length of trial..$^{95}$

82 The sub-totals do not equal the total because three attorneys did not complete the questions about experience. Their questionnaires were, however, sufficiently completed to be collated.

93 Since the reply "longer" was considered inaccurate, the question, in effect, asked only whether pretrial had caused shorter trials. See text at note 84 sapra.

04 This question was included in the opimion section (Part III) of the questionnaire because it was beheved that the responses of all judges and attorneys would he valuable on this point. The analysis of the replies is included in this section because the replies were probably based on the respondents' own experience and because the replies are germane to the general heading of time factors.

95 Although the previous questions were designed to investigate a single variable, it is possible that the judges and attorneys also based their earlier replies upon different experiences. The responses to the survey do not indicate that this was the case. 
The attorneys' report that more of their time is required to dispose of a pretried case is consistent with their report that pretrial does not induce more or earlier settlements and does not shorten trials. To realize an ovverall timesaving by pretrial, the attorney must save more time by earlier or more frequent settlements, or by shorter trials, than the time he spends in preparation for, and as a participant in, the pretrial conference. ${ }^{96}$ It appears safe to conclude that pretrial has not saved attorneys' time.

Conversely, the survey findings indicate that pretrial has not consumed additional judicial time. Whether pretrial has saved judicial time is not apparent from the survey.

\section{Quality of Disposition}

\section{a. Judge and Attorney Preparation for Trial}

Judges were asked to answer questions about the effect of pretrial upon their own preparation for trial as well as upon attorneys' preparation. Attorneys were asked only about their own preparation.

TABLE 4.

Efrect of Pretrial upon Judge and Attorney Preparation for Trial.

\begin{tabular}{|c|c|c|c|c|}
\hline \multicolumn{5}{|c|}{ a. Attorneys' Preparation } \\
\hline & $\begin{array}{c}\text { Helpful } \\
\%\end{array}$ & $\begin{array}{c}\text { Unhelpful } \\
\%\end{array}$ & $\begin{array}{c}\text { Negligible } \\
\%\end{array}$ & $\begin{array}{l}\text { Total } \\
\text { No. }\end{array}$ \\
\hline & 63 & 3 & 34 & 98 \\
\hline & 43 & 10 & 47 & 461 \\
\hline \multicolumn{5}{|c|}{ b. Judges' Preparation } \\
\hline & $\begin{array}{c}\text { Helpful } \\
\%\end{array}$ & $\begin{array}{c}\text { Unhelpful } \\
\%\end{array}$ & $\begin{array}{c}\text { Negligible } \\
\%\end{array}$ & $\begin{array}{l}\text { Total } \\
\text { No. }\end{array}$ \\
\hline udges & 58 & 2 & 40 & 97 \\
\hline
\end{tabular}

The judges' responses show that they have observed pretrial to be helpful in preparing attorneys for trial. To a slightly lesser extent, the judges find that pretrial is helpful in their own preparation for trial. Although attorneys, by a small plurality, reject the idea that pretrial affects their preparation for trial, a substantial percentage of them found pretrial to be helpful. A possible conclusion is that pretrial has a beneficial effect upon both judge and attorney preparation for trial.

\section{b. Proportion of Cases Not Finally Determined at the First Trial}

In an attempt to measure the impact of pretrial upon the quality of adjudication, a question was asked about the effect of pretrial upon the proportion of mistrials, new trials, judgments notwithstanding the verdict, appeals, and reversals. If pretrial had been reported to cause a lower proportion of these kinds of disposition, then it would have been concluded that pretrial was benefiting the quality of disposition. On the other hand, if it had been reported that a higher proportion of cases was being decided after the initial trial, then it would

96. Defense attorneys are reported to make the best use of rule 8.1 (a) (iv), which directs the presiding judge, where feasible, to assign the same pretrial date to cases involving the same attorney. Yet table 3 shows no variation between plaintiff's and defendant's counsel as to the total time spent on a case. 
have indicated that the cases were not being properly pretried. Since it was felt that individual attorneys would not have been exposed to enough cases in all these categories to provide meaningful observations, only judges were asked this question. 71 out of the 90 judges who answered reported that pretrial did not affect these kinds of dispositions.

\section{B. Findings Based on the Opinion of Judges and Attorneys}

In this section the findings based on the respondents' opinions are set forth.

\section{The Best or Most Just Result}

Judges and attorneys were asked to put time factors aside and to give their opinions of the effect of pretrial on bringing about the "most just result" (judges) or "the best result for my clients" (attorneys).

TABLE 5.

The Effect of Pretriat upon the Best or Most Just Result

$\begin{array}{lcccc} & \text { Favorable } & \text { Unfavorable } & \text { Negligible } & \text { Total } \\ & \% & \% & \% & \text { No. } \\ \text { Judges } & 37 & 2 & 61 & 162 \\ \text { Attorneys } & 34 & 5 & 61 & 537\end{array}$

This response shows judges and attorneys in substantial agreement that pretrial has had a negligible effect in bringing about the best or most just result. On the other hand, the great majority of those who beheve that pretrial has affected the result, believe that the effect of pretrial has been favorable. Although many commented that the pretrial order should not supersede the pleadings, only a few answered that pretrial adversely affected the result.

\section{Judicial Administration and Attorney Participation}

Judges and attorneys were asked for their opinions of each other's administration of, or participation in, the pretrial conference. The results show both groups to be somewhat critical of the other's performance.

TABLE 6.

Judicial Administration of and Attorney Particlpation in Pretrial

\begin{tabular}{|c|c|c|c|c|}
\hline & $\begin{array}{l}\text { Very } \\
\text { Satisfactory } \\
\%\end{array}$ & $\begin{array}{c}\text { Satisfactory } \\
\%\end{array}$ & $\begin{array}{c}\text { Unsatisfactory } \\
\%\end{array}$ & $\begin{array}{l}\text { Total } \\
\text { No. }\end{array}$ \\
\hline $\begin{array}{l}\text { Judges' opinions } \\
\text { of attorneys }\end{array}$ & 14 & 56 & 30 & 154 \\
\hline $\begin{array}{l}\text { Attorneys' opinions } \\
\text { of judges }\end{array}$ & 12 & 51 & 37 & 545 \\
\hline
\end{tabular}

This response could have important ramifications. It indicates inadequate administration of, and inadequate participation in, pretrial. It is doubtful whether the same dissatisfaction between judges and attorneys exists in other areas of litigation.

Numerous comnents in this area, however, emphasized two noteworthy factors: (1) If the attorney is dissatisfied with the rules, then he is likely to blame the judge rather than the rules; and (2) if the pretrial judge is not convinced of the worth of pretrial and does not compel active participation by the attorneys, then the attorneys are likely to be unenthusiastic and unprepared. 
On the other hand, attorneys often remarked that pretrial was being "sabotaged" by some judges. There were reports of conferences held on the morning of the trial. In at least one case no conference was held. ${ }^{97}$ Both judges and attorneys criticized the frequency of the "pro forma" pretrial conference. 98

\section{When Should Cases Be Pretried?}

\section{a. Personal Injury Cases}

Many argue that the average personal injury case should not be pretried because the issues of law and fact are simple.99 The survey findings are shown below.

TABLE 7.

When Should Personax Injury Actions be Pretried?

$\begin{array}{lccccc} & \begin{array}{c}\text { In all } \\ \text { Cases }\end{array} & \begin{array}{c}\text { In the } \\ \text { Usual Case casional Case }\end{array} & \begin{array}{c}\text { In the Oc- } \\ \text { User }\end{array} & \text { Total } \\ & \% & \% & \% & \% & \text { No. } \\ \text { Judges } & 49 & 16 & 32 & 3 & 152 \\ \text { All Attorneys } & 28 & 13 & 54 & 5 & 496 \\ \text { Plaintiffs } & 25 & 11 & 54 & 10 & 144 \\ \text { Defendants } & 15 & 14 & 68 & 3 & 169 \\ \quad \text { Both* } & 22 & 13 & 58 & 7 & 60 \\ \text { Total P.I.** } & 20 & 10 & 64 & 6 & 373 \\ \text { Others (non-P.I.) } & 52 & 13 & 34 & 1 & 123\end{array}$

* Personal injury attorneys who represent both plaintiffs and defendants.

**Personal Injury

Judges and non-personal injury attorneys favored pretrial in all personal injury actions. Yet a substantial majority of the personal injury lawyers favored pretrial only in the occasional case. The responses also show that defendant's attorneys were more strongly inclined to this response than plaintiff's attorneys. This answer was inconsistent with comments that defendant's attorneys are favorable to pretrial because they are paid on a per diem basis. ${ }^{100}$ Undoubtedly, the response supports the opposition to mandatory pretrial in personal injury actions.

\section{b. Domestic Relations Actions}

A plurality of both judges ( 40 per cent) and attorneys ( 47 per cent) felt that domestic relations actions should be pretried only in the occasional case. The comments repeatedly favored pretrying only cases involving a property settlement.

\section{c. What Should the General Rule Provide?}

The survey revealed that before the adoption of the present rules about onethird of the judges (38 per cent) and attorneys (31 per cent) had favored mandatory pretrial. ${ }^{101}$ The responses show that at the time the survey was conducted,

97 American Home Assur. Co. v. Essy, 179 Cal. App. 2d 19, 3 Cal. Rptr. 586 (1960).

98 See discussion in text at notes 102-05 infra.

99 See note 67 supra.

100 Some defense counsel were reported to attend a number of pre.trial conferences on the saune day, pursuant to rule 8.1(a) (iv), and to charge each client for a court appearance. See 20 F.R.D. 485, 514-15 (1957), for a discussion of this problem.

101 Almost one-third of the respondents either failed to answer this question or answered that they had no opinion at that time. This fact should be considered when comparing the attitude toward mandatory pretrial before and after the introduction of the rules. 
a bare majority of the judges and only one-third of the attorneys favored the present rules.

TABLE 8.

\begin{tabular}{lccccc}
\multicolumn{6}{c}{ What Shoutd tere General Rule Provide? } \\
& Mandatory & Permissive & Abolish & Other & Total \\
& $\%$ & $\%$ & $\%$ & $\%$ & No. \\
Judges & 51 & 31 & 8 & 11 & 153 \\
Attorneys & 33 & 51 & 6 & 10 & 535
\end{tabular}

This response will be discussed in the concluding section. It is sufficient to say here that every conceivable pretrial rule was suggested under the category "other."

\section{Comments}

About one-half of the respondents added comments in the section provided in the questionnaire, providing much valuable inforrnation. The most important and most frequently made comments are presented in this section in an attempt to draw a more complete picture of the California pretrial conference in action.

By far the most important and most frequent comment of judges and attorneys was that the "pro forma" pretrial conference is prevalent in California courts. Many described a "pro forma" pretrial conference in similar terms. At the call of the case for pretrial, the opposing attorneys ${ }^{102}$ hand their pretrial statements ${ }^{103}$ to the pretrial judge. The judge takes a minute to glance over the statements and then (1) corrects the title of the cause if any party has been incorrectly named, (2) dismisses the action as to umecessary or unserved parties and as to fictitious defendants, (3) ascertains those matters not really in dispute, e.g., corporate existence, (4) restates the issues remaining for trial ${ }^{101}$ or incorporates the statements of the issues in the pleadings, ${ }^{105}$ and (5) assigns a trial date and asks the parties to waive notice of trial.

It is apparent that attorneys who have participated in perfunctory conferences are biased against the present rules. Furthermore, the judges who conduct these conferences must also disapprove of the rules. Unquestionably, the survey replies were strongly affected by the perfunctory pretrial conference.

A frequent and related comment was that the same judge should pretry and try the case. The reason given was that the judge in such cases will take more pains to make the pretrial hearing productive. Even if this assumption is correct,

102 There were many reports of firms sending a junior man, not the trial attorney, to pretrial. See Cantillion v. Superior Court, 150 Cal. App. 2d 184, 309 P.2d 890 (1957). In that case, a law firm was cited for contempt for the failure of one of its attorneys to be prepared for the pretrial conference. The court held that contempt is proper only against an individual attorney and not against his firm.

${ }^{103}$ CAL. SuPER. CT. R. 8.2 provides: "[The parties or their counsel] shall prepare, and submit to the pretrial conference judge at or before the conference, a joint written statement of the matters agreed upon and a joint or separate written statement of the factual and legal contentions to be made as to the issues remaining in dispute." (Emphasis added.) Many pretrial judges, however, require only separate written statements.

104 Many pretrial orders restate the issues in a personal injury action as "negligence" and "contributory negligence."

105 See Patrick J. Ruane, Inc. v. Parker, 185 Cal. App. 2d, 488, 8 Cal. Rptr. 379 (1960). The pretrial order quoted the parties' pretrial statements and the court found them to be no more specific than the pleadings. 
courts with large calendars have found it necessary to have a pretrial calendar and to assign special pretrial judges for ordinary cases. ${ }^{106}$ Protracted cases, however, are frequently assigned to a single judge who supervises the case through all the pretrial proceedings including law and motion matters. ${ }^{107}$ By this procedure, the judge is constantly educating himself about the issues and is better prepared to try the case.

Many attorneys believed that the pretrial order should not supersede the pleadings. They argued that competent lawyers draft expositive pleadings after considerable research into the legal and factual issues of a case. A pretrial judge has only the benefit of a quick review of the pretrial statements and of a brief liearing with the attorneys before he drafts the pretrial order. It is submitted that under the present rules the judge is not given sufficient time to examine the pretrial statements of the parties, because the rules require only that the pretrial statements be submitted "at or before" the conference. 108

On the other hand, some judges and attorneys suggested two pretrial conferences. In addition to the present conference about five weeks before the trial, ${ }^{109}$ another conference would be held as soon as issue is joined. The purpose of this conference would be to limit the issues in order to himit discovery, which many complain is causing an unjustified increase in the cost of litigation. In view of a recent California Supreme Court decision, ${ }^{110}$ it would be difficult to achieve the purpose of such a conference under the existing rules. The supreme court held that discovery may be had of any matter relevant to the "subject matter,"111 as opposed to the "issues,"112 of a pending action. Even if the issues were narrowed at the proposed conference, it does not follow that the subject matter would necessarily be condensed. Therefore, it is doubtful whether the scope of discovery could be effectively confined under the existing rules.

\section{CONCLUSION}

The survey results indicate that California pretrial has realized neither the hopes of its most ardent advocates, nor the fears of its most vigorous opponents. Yet it would be a mistake to conclude that the survey definitely establishes the success or failure of pretrial in relation to the objectives that the survey attempted to measure. Although some conclusions may be drawn from the results, it is more accurate to consider the results as indications of the current attitudes toward pretrial. The survey slould be regarded as an aid to a comprehensive analysis of the efficacy of the California pretrial conference.

In the eyes of many observers pretrial under the present rules has not paid for itself in terms of time saved. Thus, the results do not indicate that pretrial

106 Pickering, The Pre-Trial Conference, 9 Hastings L.J. 117, 123-25 (1958).

107 Id. at 125; 20 F.R.D. 485, 532-37 (1957).

108 CAL. Surer. CT. R. 8.2(c); of. Cal. Judicial Council, Rules for the Superior Court: Proposed Amendments, 35 Cax. S.B.J. 461, 466-67 (1960). The Judicial Council proposed changing rule 8.2 to provide that an itemized list of special damages must be served and filed at least 10 days prior to the conference.

109 CAL. SUPER. CT. R. 8.12(a) provides that, if possible, cases shall be set for trial within five weeks of the conference.

110 Greyhound Corp. v. Superior Court, 56 A.C. 353, 364 P.2d 266, 15 Cal. Rptr. 90 (1961). Many respondents rephied before this case was decided.

111 Id. at 388, 364 P.2d at 284, 15 Cal. Rptr. at 108.

112 CAL. SupER. CT. R. 8.4 (a) provides that the court unay consider and act upon simplification of the "issues." 
has encouraged a greater number of jury waivers, has appreciably condensed trials, or has saved attorneys' time. Moreover, it is doubtful whether pretrial has caused more or earlier settlements or saved judges' time. Whether pretrial has affected the quality of civil adjudication is not clear from the survey.

If five ycars is sufficient time to judge the mandatory conference, ${ }^{113}$ then the survey may indicate that the mandatory rules have outlived their usefulness. The rules have served to educate the courts and counsel about the benefits of pretrial when faithfully administered in proper cases. But mandatory pretrial, it is submitted, has fostered perfunctory pretrial. ${ }^{114}$ Since the mandatory rule requires judges to pretry every case, a busy court often is forced to adopt an "assembly line" approach to the conference. ${ }^{115}$ In this posture, adequate time is not available for the case in which pretrial could be a great benefit. ${ }^{110}$ On the other hand, some judges and attorneys have never been convinced of the worth of the conference and make no serious attempt to accomplish anything by it. Pretrial at its worst is a costly procedure for the litigant. The litigant must reimburse his attorney for time spent in preparation for, and as a participant in, the conference. Nothing is more frustrating to the conscientious attorney than to charge his client for a useless procedure.

The survey questionnaire was drafted upon the assumption that the California controversy was benig properly fought in terms of mandatory versus permissive pretrial. ${ }^{117}$ Yet it is apparent that statement of the issue in these terms has tended to confuse two analytical questions that should be distinguished: (1) "pretrial or not?" and (2) "how much pretrial?" Thus, it has been often

113 The Judicial Council has argued that it is too early to evaluate pretrial. See $17 \mathrm{CAx}$. Judictax CouncIL BIENNIAx REP. 56 (1957-1958). Many respondents stated that pretrial cannot realize its full potential until there is a genuine abandonment of the "game" theory of litigation. These observers emphasized that this change of view will be gradual. Some indicated that the change will occur only with a new generation of lawryers. As a result, they said, pretrial cannot be judged fairly at this time.

114 The "pro forma" pretrial conference has also been recognized and criticized by the appellate courts: "Had the pretrial judge delved into the matter at all, he could have discovered the true nature of the controversy, settled the issues to be tried, required such amendments ... as might be required ... and eliminated the contention as to the pleadings now pressed upon us. He did none of these things." Patrick J. Ruane, Inc. v. Parker, 185 Cal. App. 2d 488, 493, 8 Cal. Rptr. 379, 382 (1960). When a pretrial judge passed the issue of whether the complaint stated a cause of action on to the trial judge, the appellate court remarked that this practice "patently" defeats the purpose of pretrial and should be avoided. Taylor v. S \& M Lamp Co., 190 A.C.A. 777, 12 Cal. Rptr. 323 (1961).

115 In most counties, the average length of a pretrial conference is about 15 minutes. See, e.g., CXXII THE ReCORDER (San Francisco) No. 81 at 3 (1961). The October 26, 1961, calendar for San Francisco Superior Court Department Seven (pretrial department) listed 13 cases between 9:30 and 12:00 and 14 cases between 2:00 and 4:30. Cf. Bunten, Pretrial in the Uniled States District Court for the District of Columbia, 45 KAPPA BETA PI Q. 11, 14 (1961). Mrs. Bunten, a special pretrial examiner, reports that the average length of 395 pretrial hearings (selected at random) was one hour.

${ }^{116} \mathrm{Cf}$. Bunten, supra note 115, at 11-12. Through the use of exhaustive pretrial hearings before special pretrial examiners, the District of Columbia pretrial system is designed to reduce trial time substantially and to free the time of pretrial judges for other matters.

117 It is possible that the introductory letter, see appendix A, biased the replies by phrasing the controversy in terms of mandatory versus permissive pretrial. It is further possible that the question asking for the respondents' opinions as to the best pretrial rule had the same effect. If there was a bias introduced from these sources, it is probable that it was favorable to mandatory pretrial, because no alternative rules, other than permissive pretrial, were set forth in the survey letter or questionnaire. 
assumed that only opponents of pretrial oppose the mandatory rules. Numerous comments, however, indicated that many proponents of pretrial also oppose the mandatory rules. On the other hand, many respondents reported that they favor the mandatory rules because they oppose the permissive rules. ${ }^{118}$ Since almost all of the respondents agreed that pretrial is or could be used effectively in some cases, ${ }^{119}$ the proper question is probably "how much pretrial?"120

If the rules are not mandatory, then the problem is to make optimum use of the pretrial conference by finding a workable method of selecting cases to be pretried. The following factors appear relevant to a resolution of this dilemma:121 (1) whether certain conditions should be placed upon the order, motion, or request to hold or not to hold the conference; ${ }^{122}$ (2) whether the burden of acting should rest upon the one who wants the conference or upon the one who opposes the conference; ${ }^{123}$ and (3) whether the court, or counsel, or both, should determine the cases to be pretried. ${ }^{124}$

When the Judicial Council or the legislature considers a change or amendment to the rules, the conditions upon acting and the burden of acting to bring about or to oppose the conference should be determined. These determinations having been made, one of the following may be an appropriate rule:

A pretrial conference shall (or shall not) be held unless:

(1) the court so orders, or;

(2) the court so orders on motion of:

(a) one of the parties, or

(b) all of the parties, or;

(3) all of the parties so request;

(4) one of the parties so requests.

The important point is that all of these alteruatives should be considered before the rules are changed or amended.

James G. Seely, Jr.

118 See 17 Cal. Judictax CouncII Bienniat Rep. 56 (1957-1958). A typical comment of the survey respondents was: "But-my fear is that if it [pretrial] is made permissive and not mandatory ... it won't be long before there will be very few pretrials. It is a difficult dilemma."

118 Respondents' comments heavily support this proposition. See tables 7 and 8 supra, which further demonstrate that the respondents overwhelmingly advocate pretrial in some personal injury cases and in some cases as a general rule.

120 See Zeisei, KaIven \& BuchHolz, Delay In the Court 154 (1959).

121 Another factor that should perhaps be included is whether the provision for pretrial should be made by court rule or by statute. In addition, the propriety of a state-wide rule, as opposed to a local court rule, might be examined.

122 The Los Angeles County Superior Court is presently experimenting with a pretrial innovation in personal injury cases. If both attorneys meet prior to the date set for the pretrial hearing and submit a joint pretrial statement showing that their conference has comphed with the pretrial rules, then the pretrial commissioner will prepare a proposed pretrial order. If there is no objection to this order, the judge, without further proceedings, will execute the order at the time set for the pretrial conference. The program is completely voluntary. It does not apply to cases presenting complicated issues of law or fact or to cases having been set on the special settlement calendar. XXXIX METropolrtan NEws (Los Angeles), No. 161 at 1, 8 (1961).

${ }_{123}$ See Friesen, The Minimum Requirements of a Pretrial Rule, 33 Rocky Mr. L. Rev. 523, 528-29 (1961).

124 Ibid. 


\title{
APPENDIX A
}

\section{INTRODUCTORY LETTER SENT TO JUDGES AND ATTORNEYS}

\author{
CaLIForNIa LaW REvIEW \\ UNIVERSITX OF CALIFORNIA SCHOOL OF LAW \\ BERKELEY 4, CALIFORNIA
}

August 25, 1961

The Pretrial Conference in California Stsperior Courts

In 1957, the mandatory pretrial conference was adopted for civil actions brought in Cahfornia superior courts. In 1961, the legislature very nearly enacted A.B. 1745. This bill would have amended the Code of Civil Procedure to provide for permissive pretrial conferences, i.e., on order of the court, in its discretion, or upon application of any party to the case. Many argue that the passage of A.B. 1745 would have effectively abolished pretrial in many counties.

The purpose of this survey is to study the California experience with pretrial. We are sending questionnaires to all superior court judges and selected attorneys. (Attorneys: If you are a member of a firm and do not normally participate in pretrial conferences or trials, please pass the enclosed questionnaire to a member of your firn who does.)

We shall be most grateful for your considered replies to the enclosed questionnaire. We shall be grateful, also, if you will mail back your replies within ten days.

We have numbered the questionnaires so that we may determine if the returns represent state-wide coverage. We are interested only in statistical results. We shall process your reply in strict confidence.

Thank you for your time and consideration.

Respectfully,

JaMes G. Seely, Jr.

JGS:aw

Enclosures

\section{APPENDIX B \\ QUESTIONNAIRE SENT TO SUPERIOR COURT JUDGES \\ SUPERTOR COURT JUDGES}

(All judges please answer parts I, III, and IV.)

I. General Information:

A. I have been a superior court judge since. (year).

B. If assignments are made by department in your county, what is your present assignment?

C. Please estimate the percentage of your time since 1957 in the following assignments:

(1) presiding at pretrial conferences:

(2) presiding at the trial of cases which have been pretried:

(3) other (please specify):

(Please answer the questions in part II only if you presided at the trial of cases which would have been subject to pretrial prior to 1957 and have presided at the trial of cases which have been pretried since 1957.)

II. Please compare non-pretried cases prior to 1957 with pretried cases based on your own observation:

A. Because of pretrial, attorneys are:

(1) better prepared for trial

(2) not as well prepared for trial

(3) prepared to the same extent

B. The pretrial order has the following effect on my own preparation for trial:
(1) helpful
(2) nnhelpful.
(3) neghigible.

C. Because of pretrial, the proportion of jury waivers is:
(1) greater
(2) smaller.
(3) unchanged.

D. Because of pretrial, trials are:
(1) longer.
(2) shorter.
(3) unchanged 
E. Because of pretrial, the proportion of mistrials, new trials, judgments n.o.v., appeals and reversals is:
(1) greater
(2) smaller.
(3) unchanged.

F. Because of pretrial, the proportion of settlements prior to verdict is:
(1) greater.
(2) smaller
(3) unchanged

G. Because of pretrial, settlements occur:
(1) earlier.
(2) later.
(3) unchanged

III. Your opinion of the effect of pretrial:

A. Because of pretrial, the total judicial time spent on the disposition of a case is:
(1) longer.
(2) shorter
(3) about the same

B. Time factors aside, pretrial aids in reaching a:
(1) more just result
(2) less just result
(3) no change has been observed

C. Participation in pretrial by attorneys has been:
(1) very satisfactory.
(2) satisfactory
(3) unsatisfactory

D. Personal injury actions:

(1) should be pretried in all cases.

(2) should be pretried in the usual case.

(3) should be pretried in the occasional case.

(4) never should be pretried.

E. Domestic relations actions:

(1) should be pretried in all cases........ (2) should be pretried in the usual case

(3) should be pretried in the occasional case.

(4) never should be pretried.

F. Before pretrial was adopted, I was in favor of:

(1) mandatory pretrial.

(2) permissive pretrial (on order of the court, in its discretion, or upon application of any party to the case)

(3) other (please specify):

G. I now feel that pretrial sbould be:

(1) mandatory

(2) permissive

(3) other (please specify):

IV. I offer these comments:

\section{APPENDIX C \\ QUESTIONNAIRE SENT TO ATTORNEYS ATTORNEYS}

(All attorneys please answers parts I, II, and IV.)

I. General Information:

A. I have been practicing law in California simce (year).

B. I conduct the balance of my practice in the following county (counties):

C. Prior to the adoption of pretrial in 1957, I tried the following number of cases per year which would have been subject to pretrial:

(1) less than 5 cases

(2) 5 - 10 cases

(3) more than 10 cases

(4) not in practice prior to 1957

D. Since 1957 , I have tried the following number of cases subject to pretrial:
(1) less than 10
(2) $10-20$
(3) more than 20

E. Since 1957 , I have participated in approximately the following number of pretrial conferences:
(1) less than 10
(2) $10-20$
(3) more than 20

F. If you are a nember of a firm, what is the total membership of the firm, mcluding associates?
(1) less than 5
(2) $5-10$
(3) inore than 10
(4) not a member of a firm

G. If your practice included substantial personal injury work, do you represent:
(1) primarily plaintiffs
(2) primarily defendants
(3) both
(4) not applicable 
(Please answer the questions in part II only if you tried cases which would have been subject to pretrial prior to 1957 and have tried cases which have been pretried since 1957.)

II. Please compare non-pretried cases prior to 1957 with pretried cases based on your own observation:

A. Because of pretrial, the proportion of my cases which have been settled prior to verdict is:
(1) greater
(2) smaller
(3) unchanged

B. Because of pretrial, I find that settlement usually occurs:
(1) earlier
(2) later
(3) unchanged

C. The effect of pretrial on iny preparation for trial is:
(1) helpful
(2) unhelpful.
(3) negligible

D. Because of pretrial, I waive jury trials:
(1) more frequently
(2) less frequently
(3) about the same

E. Because of pretrial, I find that trials are:
(1) longer
(2) shorter
(3) unchanged

III. Your opinion of the effect of pretrial:

A. Because of pretrial, the total attorney time spent on a case is:
(1) longer
(2) shorter
(3) about the same

B. Time factors aside, the effect of pretrial on securing the best results for my clients has been:
(1) favorable
(2) unfavorable
(3) negligible

C. Personal injury cases:

(1) should be pretried in all cases.......... (2) should be pretried in the usual case

(3) should be pretried in the occasional case.......... (4) never should be pretried

D. Domestic relations cases:
(1) should be pretried in all cases.
(2) should be pretried in the usual case
(3) should be pretried in the occasional case
(4) never should be pretried..........

E. Judicial administration of pretrial has been:
(1) very satisfactory
(2) satisfactory
(3) unsatisfactory

F. Before pretrial was adopted, I was in favor of:

(1) mandatory pretrial

(2) permissive pretrial (on order of the court, in its discretion, or upon application of any party to the case)

(3) other (please specify):

G. I now feel that pretrial sliould be:
(1) mandatory
(2) permissive
(3) other (please specify):

IV. I offer these comments: 